\title{
EHMTI-0116. Tension type primary headaches and fibromyalgia: strong correlations
}

\author{
A Karapetyan ${ }^{1 *}, \mathrm{H}$ Manvelyan ${ }^{2}$ \\ From 4th European Headache and Migraine Trust International Congress: EHMTIC 2014 \\ Copenhagen, Denmark. 18-21 September 2014
}

\section{Introduction}

Fibromyalgia (FM) is becoming more widespread and better diagnosed, which leads to understanding of its mechanisms, presence of possible comorbidities. Tension Type Headaches (TTH) remain most distributed among primary headaches, and we found strong correlations between FM and TTH.

Aim of study is unveiling the distribution of TTH in patients with FM, and measure the quality of life of patients with generalized pain syndromes.

\section{Methodes}

159 patients with FM, mean age $49 \pm 14,101$ women and 58 men, were evaluated for other pain syndromes and quality of life.

\section{Results}

114 patients $(71.6 \%)$ had simultaneously headaches, distributed as follows: TTH in 78 (49\% from all included or $68 \%$ of randomized), migraine in 15 (9.4\% and $13 \%$ respectively), cluster headaches in $6(3.8 \%$ and $5.2 \%)$, 5 had Sluder syndrome (3\% and 4.4\%), 3 had trigeminal neuralgia (2\% and 2.6\%), and seven patients suffers of headaches or facial pain due to sinusitis, injury, inflammation.

\section{Results}

The number of patients with comorboid headaches was surprisingly high in FM population, making up 2/3, although the main distribution of the types of headaches was almost as in general population, with leading number of TTH patients (68\% of randomized). Patients with comorboid headaches had worse scores of quality of life comparing to those with isolated FM.

${ }^{1}$ Family Medicine and Neurology, Yerevan State Medical University after Heratsi, Yerevan, Armenia

Full list of author information is available at the end of the article

\section{Conclusion}

Despite of heterogeneity of FM in its clinical presentations, presence of TTH must be assessed. There are strong correlations between FM and TTH, and both could be considered as presentations of Generalized Pain Syndrome, with probable similar etiology and mechanisms.

No conflict of interest.

\section{Authors' details}

${ }^{1}$ Family Medicine and Neurology, Yerevan State Medical University after Heratsi, Yerevan, Armenia. ${ }^{2}$ Neurology, Yerevan State Medical University after Heratsi, Yerevan, Armenia.

Published: 18 September 2014

doi:10.1186/1129-2377-15-S1-C42

Cite this article as: Karapetyan and Manvelyan: EHMTI-0116. Tension type primary headaches and fibromyalgia: strong correlations. The Journal of Headache and Pain 2014 15(Suppl 1):C42.

\section{SpringerOpen ${ }^{\circ}$}

(c) 2014 Karapetyan and Manvelyan; licensee Springer. This is an Open Access article distributed under the terms of the Creative Commons Attribution License (http://creativecommons.org/licenses/by/2.0), which permits unrestricted use, distribution, and reproduction in any medium, provided the original work is properly cited.
Submit your manuscript to a SpringerOpen ${ }^{\circ}$ journal and benefit from:

- Convenient online submission

- Rigorous peer review

- Immediate publication on acceptance

- Open access: articles freely available online

- High visibility within the field

Retaining the copyright to your article

Submit your next manuscript at $>$ springeropen.com 